\title{
Habituasi Kelompok Bercampur Macaca tonkeana-hecki: Peluang Dan Tantangan
}

\section{Habituating of Mixed Group of Macaca tonkeana-hecki: Opportunities and Challenges}

\author{
Wanda Damayanti ${ }^{*}$, Fitriana, M Syarif Indra Gunawan, Annawaty dan Fahri \\ Jurusan Biologi, Fakultas MIPA, Universitas Tadulako, \\ Jl.Soekarno Hatta km 9Tondo, Palu 94118, Sulawesi Tengah, Indonesia
}

\begin{abstract}
Habituating of mixed group of Macaca tonkeana-hecki was held in January to July 2016 in Pangi Binangga Nature Reserve, Central Sulawesi, Indonesia. According to the local people, there were two groups that often seen by the community in the area. The first one called Salubay group were found in the place where fruit merchant throw away their wastes while the second one called Gunung Batu group were found around cliffs, ravines and river. Salubay group wasdifficult tobe found during the study, we cannot make approach any member of this group and we didn't know their home range yet. In contrast, Gunung Batu group wasmore frequently found during habituation. We can approach the group during habituation process. There were 29 and 23 heads of macaques found in the first census (January-February 2016) and second census (March-July 2016), respectively. We can identify 3 obstacles during habituation i.e. steep location, conflict with local people and home range of macaques that located nearby the highway. All obstacles were properly discussed in this article.
\end{abstract} Sulawesi

Keywords: Habituation, Macaca tonkeana-hecki, Pangi Binangga Nature Preserve,

\begin{abstract}
ABSTRAK
Habituasi Kelompok Bercampur Macaca tonkeana-hecki telah dilaksanakan pada bulan Januari sampai Juli 2016 di Cagar Alam Pangi Binangga, Sulawesi Tengah, Indonesia. Menurut informasi penduduk lokal, terdapat dua kelompok yang sering terlihat yaitu kelompok Salubay yang lokasinya berada di tempat pembuangan buah-buahan dan sayuran busuk oleh para penjual buah yang merupakan warga lokal setempat dan kelompok Gunung Batu yang berada di sekitar tebing, jurang dan dekat dengan sungai. Kelompok Salubay cukup sulit ditemukan, dan belum ada individu yang dapat di dekati, dari kelompok ini dan jalur home range mereka belum diketahui. Kelompok Gunung Batu merupakan kelompok yang lebih sering ditemukan selama proses habituasi dan kami dapat mendekati seluruh anggota kelompok selama habituasi dilakukan. Pada sensus pertama (JanuariFebruari 2016) ditemukan 29 individu, sedangkan pada sensus kedua (Maret-Juli 2016) dijumpai 23 individu. Tantangan yang dihadapi selama proses habituasi yang meliputi: lokasi penelitian yang berada di daerah yang curam dan terjal, konflik dengan masyarakat lokal dan lokasi home range Macaca yang berada dekat dengan jalan poros dijelaskan dengan rinci dalam artikel ini.
\end{abstract}

\section{Kata kunci: Habituasi, Macaca tonkeana-hecki, Cagar Alam Pangi Binangga, Sulawesi}




\section{LATAR BELAKANG}

Habituasi yaitu masa pembiasaan pengamat terhadap obyek hewan yang akan diteliti. Habituasi merupakan proses yang berkelanjutan, dikarenakan komposisi kelompok yang dapat berubah selama periode habituasi (imigrasi, kelahiran dan kematian) (Joanna and Deborah, 2003). Kontak langsung yang terjadi secara berulang-ulang pada genus primata nonmanusia dan manusia dapat mengurangi ketakutan dan menyebabkan pembiasaan perilaku hewan terhadap kehadiran pengamat (Elizabeth and Anna, 2003).

Salah satu cara untuk mempermudah proses habituasi ialah dengan mengetahui jalur home range. Beberapa peneliti primata melaporkan dengan rentang home range yang kecil, kontak langsung akan sering terjadi (Elizabeth and Anna, 2003). Cara lain untuk bertemu mereka yaitu dengan mencari lokasi istrahat (pohon tidur). Joanna and Deborah (2003), melaporkan bahwa berada di lokasi istrahat sebelum mereka bangun tidur di pagi hari akan lebih mudah untuk mengikuti jalur home range.

Sebagian besar primata dapat mengidentifikasi wajah manusia dengan cepat, oleh karena itu diperlukan pengamat yang sama selama melakukan habituasi. Macaca sensitif terhadap jumlah pengamat yang hadir. Mereka dapat mengubah perilaku mereka dengan peningkatan jumlah pengamat yang hadir (Elizabeth and Anna, 2003), karena itu akan lebih baik jika jumlah pengamat hanya satu atau dua dan merupakan orang yang sama. Beberapa hal yang dapat membantu yaitu: konsisten dalam berpenampilan (memakai pakaian, topi dan tas yang sama). Pengamat harus bersikap tenang dan mencoba untuk 'meyakinkan' mereka dengan cara meniru perilaku mereka (Curtis, 1998).

Beberapa penelitian melaporkan Macaca nigra akan memanjat pohon, menunjukkan taring dan bersuara keras ketika dikunjungi oleh jumlah pengamat yang banyak (Kinnaird and O'Brien, 1996), lain hal nya pada $M$. archtoides akan berlari dan bersembunyi jika kehadiran pengamat melebihi satu atau dua orang (Rasmussen, 1991) dan Eulemur mongoz menunjukkan tanda-tanda agitasi jika mereka tidak mengetahui kehadiran pengamat ataupun pengamat melebihi dari satu sampai dua orang (Curtis, 1998).

Secara umum, Macaca spp. merupakan spesies oportunisme yang relatif mudah terhabituasi. Mereka merupakan hewan extrovert dan beradaptasi dengan mudah untuk mengubah perilaku mereka dari perubahan habitat (Elizabeth and Anna, 2003).

Salah satu kawasan hutan tropis yang merupakan hutan dataran rendah di Sulawesi yaitu Cagar Alam Pangi Binangga (yang biasa disebut kebun kopi) yang terdapat di Sulawesi bagian tengah. Watanabe et al., (1991), melaporkan bahwa dikawasan tersebut ditemukan dua jenis Macaca yaitu M. tonkeana dan M. hecki. Tulisan ini menyajikan proses habituasi kelompok bercampur M. tonkeanahecki serta tantangannya di Cagar Alam Pangi Binangga, Sulawesi Tengah, Indonesia.

\section{BAHAN DAN METODE}

Alat yang digunakan yaitu teropong binokuler untuk mengamati Macaca. Perhitungan jumlah populasi dilakukan secara sederhana 
dengan menggunakan hand counter.

Dokumentasi diambil menggunakan kamera

DSLR (lensa 70-300 mm), data dan informasi penting dicatat pada buku lapangan. Untuk menentukan titik koordinat dan ketinggian lokasi penelitian menggunakan GPS (Global Positioning System). Bahan makanan sebagai umpan yang digunakan yaitu buah-buahan yang dibawa dari luar lokasi penelitian.

\section{HASIL DAN PEMBAHASAN PRA-HABITUASI}

Mengamati Macaca yang dipelihara oleh masyarakat untuk mengetahui pola dasar aktivitas mereka seperti: lokomotor, postur, ekspresi wajah, mencari makan, berdandan, bermain, sexual dan interaksi perkelahian. Mengamati Macaca peliharaan juga akan memberikan kesempatan mengetahui bagaimana membedakan individu jantan, betina dan mengklasifikasikan umur untuk mempermudah pengamatan di alam liar (Elizabeth and Anna, 2003).

Habituasi Macaca dilakukan di Cagar Alam Pangi Binangga, di Kabupaten Parigi Moutong, Provinsi Sulawesi Tengah, Indonesia pada koordinat $\mathrm{LS}=00^{\circ} 43^{\prime} 36,6^{\prime \prime}, \quad \mathrm{LT}=$

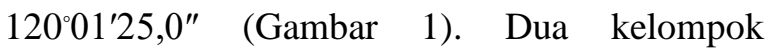
Macaca yang sering terlihat oleh masyarakat yaitu kelompok Salubay berada di area tempat pembuangan buah-buah dan sayuran busuk masyarakat setempat, serta kelompok Gunung Batu yang berada di sekitar tebing, jurang dan dekat dengan sungai.

Sebagai daerah perbatasan antar spesies, di Cagar Alam Pangi Binangga terdapat dua spesies
Macaca yaitu $M$. tonkeana dan M. hecki (Watanabe et al., 1991). Untuk mengetahui jenis Macaca kami menggunakan karakter eksternal menurut Watanabe et al., (1991) yaitu 1). jambul (mahkota), 2). rambut pipi kontras terhadap jenggot, 3). warna rambut leher, 4). warna rambut dada, 5). warna rambut lengan, 6). bidang datar "gluteal fields" (yang tidak ditumbuhi rambut) kiri dan kanan ekor, 7). bentuk tulang pantat, 8). warna rambut paha belakang, 9). warna rambut betis, 10). warna pantat dan 11). ukuran ekor.

\section{HABITUASI}

Sebanyak 30 kali kunjungan ke lokasi kelompok Salubay (1 hari = 1 kali kunjungan), namun total perjumpaan yaitu 2 kali dan dengan durasi waktu yang singkat. Kelompok ini merupakan kelompok yang sulit ditemukan, belum ada individu yang kami dapat dekati dikelompok ini dan kami belum mengetahui jalur home range mereka.

Kelompok Gunung Batu merupakan kelompok yang lebih sering ditemukan (dengan perjumpaan 12 kali selama 30 kali kunjungan). Kami menunggu mereka di sekitar tebing dan jurang atau di tepi sungai yang merupakan lokasi pertama kali kami bertemu. Lokasi tersebut menjadi lokasi yang strategis karena terdapat pohon tidur, sumber makanan dan sungai. Kami menunggu di lokasi tersebut mulai pukul 05.30 WITA (waktu Macaca turun dari pohon tidur setelah istrahat dan memulai aktivitas kembali) sampai pukul 18.00 WITA (naik kembali kepohon tidur untuk istrahat). Secara umum, individu yang mudah kami dekati pada awal 
proses habituasi yaitu remaja, sebaliknya yang hasil pengamatan selama habituasi disajikan pada sulit kami dekati yaitu dewasa dan anak. Data Tabel 1.

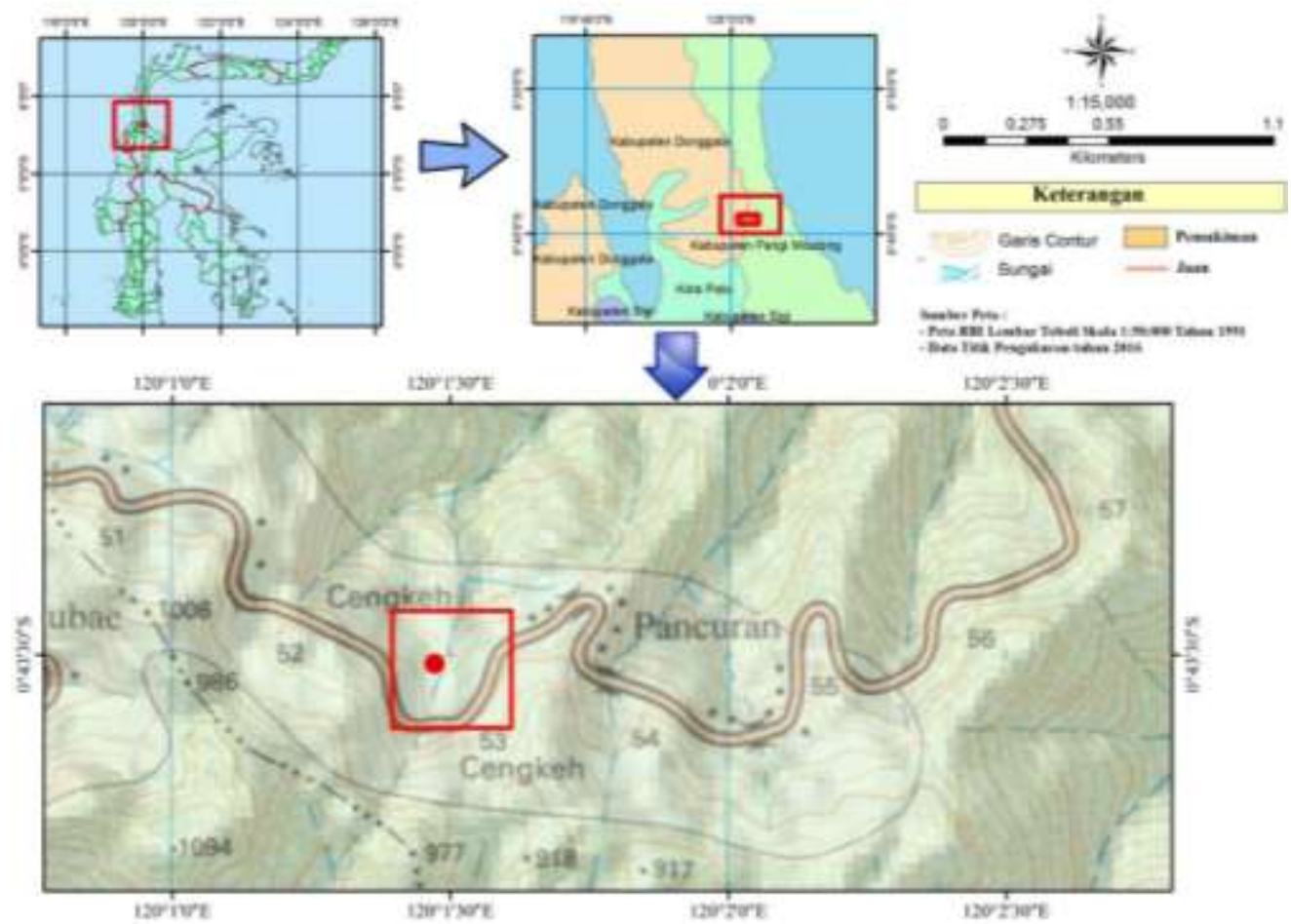

Gambar 1. Peta Lokasi Penelitian

Pada saat bertemu dengan mereka, kami membiasakan memberi pakan berupa buahbuahan yang jarang diberikan oleh pengunjung atau warga lokal. Pada minggu pertama dan minggu kedua habituasi, hanya beberapa individu yang mengambil buah yang diberikan dan individu lainnya masih bersembunyi ataupun mengambil buah dan menggertakkan taring. Akan tetapi pada minggu ketiga dan keempat semua anggota kelompok mengambil buah yang diberikan dan beberapa individu sudah mulai berani mendekati kami dengan jarak terdekat yaitu \pm 6 meter (individu jantan remaja).

\begin{tabular}{lllll}
\hline \multirow{2}{*}{ Individu } & \multicolumn{1}{c}{ Minggu-1 } & Minggu-2 & Minggu-3 & Minggu-4 \\
\cline { 2 - 5 } & & Mengambil pakan & $\begin{array}{l}\text { Mengambil pakan } \\
\text { dan menunggu di }\end{array}$ & $\begin{array}{l}\text { Mengambil pakan } \\
\text { dan mendekati } \\
\text { pengamat }\end{array}$ \\
\hline Jantan Dewasa A & $\begin{array}{l}\text { Mengambil pakan } \\
\text { yang diberikan } \\
\text { kemudian }\end{array}$ & $\begin{array}{l}\text { yang diberikan } \\
\text { kemudian }\end{array}$ & $\begin{array}{l}\text { lokasi yang sama } \\
\text { bersembunyi }\end{array}$ & \\
& bersembunyi & Mengambil pakan & Mengambil pakan & Mendekati sumber \\
& Menggoyangkan & yang diberikan & dan menunggu di & pakan dan \\
pengamat
\end{tabular}




\begin{tabular}{|c|c|c|c|c|}
\hline & yang diberikan & yang diberikan & $\begin{array}{l}\text { dan menunggu di } \\
\text { lokasi yang sama }\end{array}$ & $\begin{array}{l}\text { pakan dan } \\
\text { pengamat }\end{array}$ \\
\hline Jantan Remaja A & $\begin{array}{l}\text { Mengambil pakan } \\
\text { yang diberikan }\end{array}$ & $\begin{array}{l}\text { Mengambil pakan } \\
\text { yang diberikan }\end{array}$ & $\begin{array}{l}\text { Mengambil pakan } \\
\text { dengan jarak } \pm 6 \\
\text { meter dengan } \\
\text { pengamat }\end{array}$ & $\begin{array}{l}\text { Mengambil pakan } \\
\text { dan mulai } \\
\text { mendekati sumber } \\
\text { pakan (karung) }\end{array}$ \\
\hline Jantan Dewasa C & $\begin{array}{l}\text { Menggertakkan } \\
\text { taring ketika bertemu }\end{array}$ & $\begin{array}{l}\text { Berteriak kemudian } \\
\text { mengambil pakan } \\
\text { yang diberikan }\end{array}$ & $\begin{array}{l}\text { Mengambil pakan } \\
\text { dan menunggu di } \\
\text { lokasi yang sama }\end{array}$ & $\begin{array}{l}\text { Mengambil pakan } \\
\text { dengan jarak } \pm 8 \\
\text { meter dengan } \\
\text { pengamat }\end{array}$ \\
\hline Anak A & $\begin{array}{l}\text { Bersembunyi di balik } \\
\text { semak }\end{array}$ & $\begin{array}{l}\text { Mengambil pakan } \\
\text { lalu bersembunyi }\end{array}$ & $\begin{array}{l}\text { Mengambil pakan } \\
\text { yang diberikan dan } \\
\text { berlindung kepada } \\
\text { individu lainnya }\end{array}$ & $\begin{array}{l}\text { Mengambil pakan } \\
\text { yang diberikan }\end{array}$ \\
\hline Betina Dewasa B & $\begin{array}{l}\text { Mengambil pakan } \\
\text { lalu bersembunyi }\end{array}$ & $\begin{array}{l}\text { Mengambil pakan } \\
\text { yang diberikan dan } \\
\text { menggertakkan } \\
\text { taring }\end{array}$ & $\begin{array}{l}\text { Mengambil pakan } \\
\text { yang diberikan } \\
\text { kemudian berlari }\end{array}$ & $\begin{array}{l}\text { Mengambil pakan } \\
\text { kemudian } \\
\text { menggoyangkan } \\
\text { pohon }\end{array}$ \\
\hline Betina Remaja A & $\begin{array}{l}\text { Mengambil pakan } \\
\text { yang diberikan dan } \\
\text { berteriak }\end{array}$ & $\begin{array}{l}\text { Mengambil pakan } \\
\text { yang diberikan }\end{array}$ & $\begin{array}{l}\text { Mengambil pakan } \\
\text { dan menunggu di } \\
\text { lokasi yang sama }\end{array}$ & $\begin{array}{l}\text { Mendekati sumber } \\
\text { pakan (karung) dan } \\
\text { berteriak }\end{array}$ \\
\hline Betina Remaja B & $\begin{array}{l}\text { Berteriak dan } \\
\text { menggertakkan } \\
\text { taring }\end{array}$ & $\begin{array}{l}\text { Berteriak dan } \\
\text { mengambil pakan } \\
\text { yang diberikan }\end{array}$ & $\begin{array}{l}\text { Mengambil pakan } \\
\text { dan menunggu di } \\
\text { lokasi yang sama }\end{array}$ & $\begin{array}{l}\text { Mendekati sumber } \\
\text { pakan dan berteriak } \\
\text { saat mengambil }\end{array}$ \\
\hline Anak B & Bersembunyi & $\begin{array}{l}\text { Mengambil pakan } \\
\text { lalu bersembunyi }\end{array}$ & $\begin{array}{l}\text { Mengambil pakan } \\
\text { lalu bersembunyi }\end{array}$ & $\begin{array}{l}\text { Mengambil pakan } \\
\text { dan menunggu di } \\
\text { lokasi yang sama }\end{array}$ \\
\hline Anak C & $\begin{array}{l}\text { Mengambil pakan } \\
\text { yang diberikan } \\
\text { kemudian berlindung } \\
\text { kepada individu } \\
\text { lainnya }\end{array}$ & $\begin{array}{l}\text { Mengambil pakan } \\
\text { yang diberikan }\end{array}$ & $\begin{array}{l}\text { Mengambil pakan } \\
\text { dan menunggu di } \\
\text { lokasi yang sama }\end{array}$ & $\begin{array}{l}\text { Mendekati sumber } \\
\text { pakan }\end{array}$ \\
\hline Betina Dewasa $\mathrm{C}$ & $\begin{array}{l}\text { Mengambil pakan } \\
\text { kemudian } \\
\text { bersembunyi }\end{array}$ & $\begin{array}{l}\text { Mengambil pakan } \\
\text { yang diberikan dan } \\
\text { menggertakan } \\
\text { taring }\end{array}$ & $\begin{array}{l}\text { Mengambil pakan } \\
\text { dan menunggu di } \\
\text { lokasi yang sama }\end{array}$ & $\begin{array}{l}\text { Mendekati sumber } \\
\text { pakan dan berteriak } \\
\text { ketika mengambil } \\
\text { pakan }\end{array}$ \\
\hline Betina Remaja C & $\begin{array}{l}\text { Mengambil pakan } \\
\text { yang diberikan dan } \\
\text { menunggu ditempat } \\
\text { yang sama }\end{array}$ & $\begin{array}{l}\text { Berteriak ketika } \\
\text { mengambil pakan } \\
\text { yang diberikan }\end{array}$ & $\begin{array}{l}\text { Mengambil pakan } \\
\text { dan menunggu di } \\
\text { lokasi yang sama }\end{array}$ & $\begin{array}{l}\text { Mendekati sumber } \\
\text { pakan }\end{array}$ \\
\hline Jantan Dewasa D & Bersembunyi & $\begin{array}{l}\text { Mengambil pakan } \\
\text { lalu bersembunyi }\end{array}$ & $\begin{array}{l}\text { Mengambil pakan } \\
\text { dan menunggu di } \\
\text { lokasi yang sama }\end{array}$ & $\begin{array}{l}\text { Berteriak dan } \\
\text { menggertakkan } \\
\text { taring ketika } \\
\text { mencoba mendekati } \\
\text { pengamat }\end{array}$ \\
\hline Anak D & Bersembunyi & $\begin{array}{l}\text { Mengambil pakan } \\
\text { lalu bersembunyi }\end{array}$ & $\begin{array}{l}\text { Mengambil pakan } \\
\text { dan menunggu di } \\
\text { lokasi yang sama } \\
\text { kemudian } \\
\text { bersembunyi }\end{array}$ & $\begin{array}{l}\text { Mengambil pakan } \\
\text { dan menunggu } \\
\text { dilokasi yang sama }\end{array}$ \\
\hline Jantan Dewasa E & $\begin{array}{l}\text { Mengambil pakan } \\
\text { kemudian } \\
\text { bersembunyi }\end{array}$ & $\begin{array}{l}\text { Mengambil pakan } \\
\text { kemudian } \\
\text { bersembunyi }\end{array}$ & $\begin{array}{l}\text { Mengambil pakan } \\
\text { dan menggertakkan } \\
\text { taring kemudian } \\
\text { bersembunyi }\end{array}$ & $\begin{array}{l}\text { Mengambil pakan } \\
\text { dan menunggu } \\
\text { dilokasi yang sama }\end{array}$ \\
\hline Jantan Remaja B & $\begin{array}{l}\text { Mengambil pakan } \\
\text { yang diberikan }\end{array}$ & $\begin{array}{l}\text { Mengambil pakan } \\
\text { yang diberikan dan } \\
\text { menggertakkan } \\
\text { taring }\end{array}$ & $\begin{array}{l}\text { Mengambil pakan } \\
\text { dan menunggu di } \\
\text { lokasi yang sama }\end{array}$ & $\begin{array}{l}\text { Mendekati } \\
\text { pengamat dan } \\
\text { berlari } \\
\text { menggoyangkan } \\
\text { pohon }\end{array}$ \\
\hline
\end{tabular}




\begin{tabular}{lllll}
\hline Betina Remaja D & $\begin{array}{l}\text { Mengambil pakan } \\
\text { yang diberikan dan } \\
\text { berteriak saat } \\
\text { mengambil }\end{array}$ & $\begin{array}{l}\text { Mengambil pakan } \\
\text { kemudian } \\
\text { bersembunyi }\end{array}$ & $\begin{array}{l}\text { Mengambil pakan } \\
\text { yang diberikan }\end{array}$ & $\begin{array}{l}\text { Mendekati sumber } \\
\text { pakanyang } \\
\text { diberikan }\end{array}$ \\
\hline Jantan Remaja C & $\begin{array}{l}\text { Mengambil pakan } \\
\text { yang diberikan }\end{array}$ & $\begin{array}{l}\text { Mengambil pakan } \\
\text { dan menunggu di } \\
\text { lokasi yang sama }\end{array}$ & $\begin{array}{l}\text { Mengambil pakan } \\
\text { yang diberikan } \\
\text { dengan dengan } \\
\text { jarak } \pm 7 \text { meter } \\
\text { dengan pengamat }\end{array}$ & $\begin{array}{l}\text { Mendekati } \\
\text { pengamat dan } \\
\text { mencoba mencuri } \\
\text { pakan }\end{array}$ \\
\hline Betina Dewasa D & Berteriak dan & Mengambil pakan & $\begin{array}{l}\text { Mengambil pakan } \\
\text { dan menggertakkan } \\
\text { taring }\end{array}$ & $\begin{array}{l}\text { Mengambil pakan } \\
\text { dan bersembunyi }\end{array}$ \\
\hline
\end{tabular}

Tabel 1. Proses habituasi pada bulan Januari 2016

\section{KELOMPOK GUNUNG BATU}

Habituasi dilakukan setiap hari (JanuariFebruari 2016) dan setiap akhir pekan (MaretJuli 2016). Kami menandai kelompok gunung batu dengan sebutan hecki, meskipun jantan utama (alfamale) mereka yaitu M. tonkeana (Gambar 2). Kelompok gunung batu terdiri dari 23 individu (Tabel 2). Pada fase bayi, kami belum dapat menentukan jenis kelamin karena fase ini merupakan perkembangan awal Macaca sehingga memiliki kesamaan (Watanabe et al., 1991). Sensus pertama (Januari-Februari 2016) terhitung ada 29 individu dan sensus kedua (Maret-Juli 2016) terdapat 23 individu. Perbedaan jumlah individu pada dua kali sensus dikarenakan 1 dewasa jantan keluar dari kelompok dan menjadi individu yang hidup soliter, 2 dewasa mati (menurut wawancara warga lokal) sedangkan 3 remaja jantan tidak ada informasi.

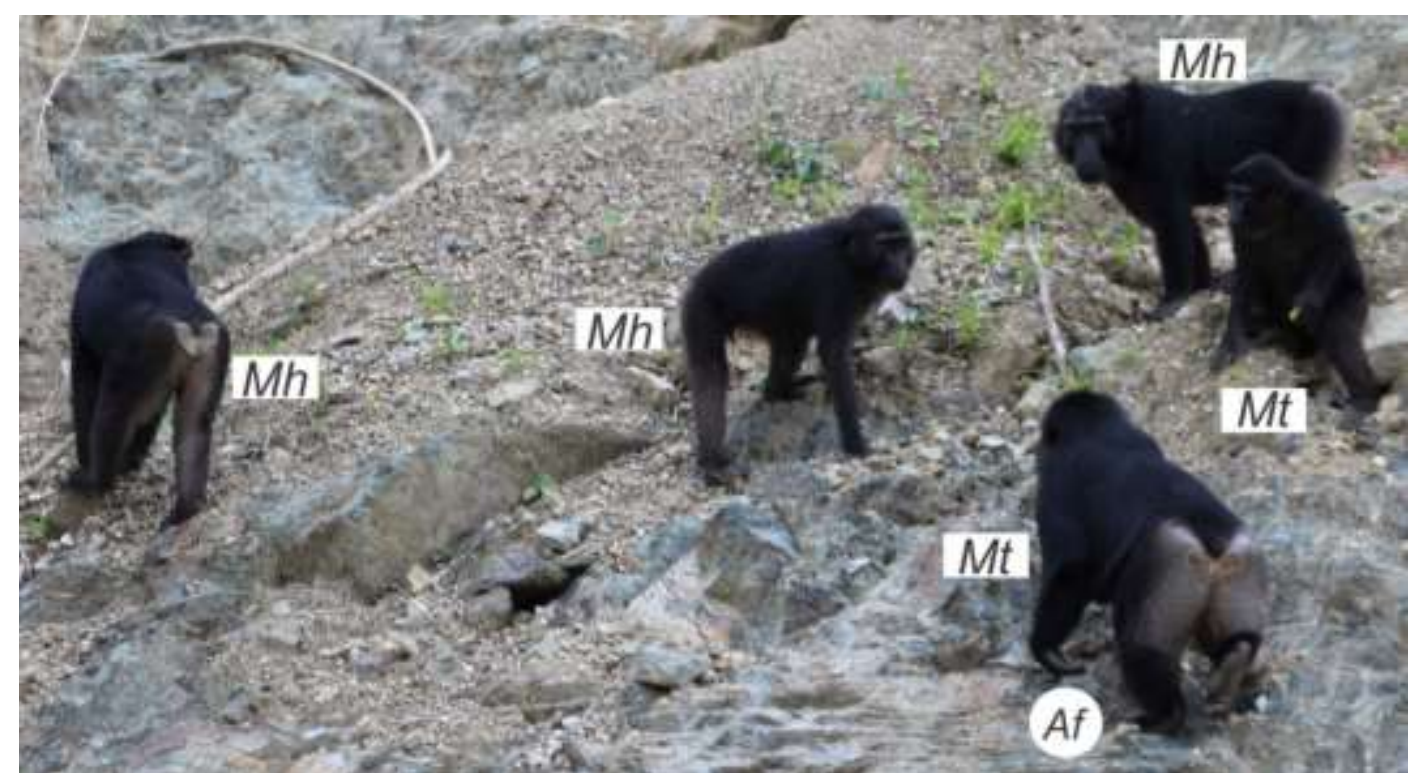

Gambar 2. Kelompok Gunung Batu: $\mathrm{Mt}=M$. tonkeana (2 individu), $\mathrm{Mh}=$ M. hecki (3 individu), Af= Alfamale 


\begin{tabular}{lccc}
\hline \multirow{2}{*}{ Kategori Umur } & \multicolumn{3}{c}{ Sensus Periode November-Desember 2016 } \\
\cline { 2 - 4 } & Jantan & Betina & Total \\
\hline Bayi & - & - & 3 \\
Anak & - & - & 4 \\
Remaja & 3 & 4 & 7 \\
Dewasa & 5 & 4 & 9 \\
\hline Total & 8 & 8 & 23 \\
\hline
\end{tabular}

Tabel 2. Jumlah individu kelompok bercampur M. tonkeana-hecki

Setelah mengklasifikasikan umur, kami memberi nama beberapa individu yang dapat didekati untuk mempermudah dalam mengenali mereka (Tabel 3). Kami memberi nama sesuai dengan karakter yang mudah dikenali yang ada pada setiap individu. Salah satu individu yang diberi nama yaitu 'Codet' (memiliki bekas luka di bagian pipi) merupakan individu remaja jantan dan yang pertama kali terhabituasi dengan baik (Gambar 2). Codet terhabituasi dengan baik pada minggu ke sebelas (pada minggu ketiga bulan maret) dan jarak dengan pengamat sekitar \pm 1 meter.

\section{TANTANGAN}

Cagar Alam Pangi Binangga memiliki kelerengan yang sangat curam yaitu 81,65\% dan ketinggian 970-1037 $\mathrm{m}$ di atas permukaan laut (BKSDA, 2010). Lokasi yang curam dan terjal serta cuaca yang buruk (hujan dan kabut tebal) menjadi tantangan tersendiri dalam mencari daerah home range mereka. Selain itu, lokasi ini banyak ditumbuhi Calamus sp. (rotan) yang memiliki batang berduri tajam juga menjadi tantangan dalam mengikuti mereka untuk mengelilingi home range. Habituasi juga terhambat ketika terjadi konflik dengan warga lokal, mereka melarang kami membiasakan memberi pakan kepada Macaca. Hal tersebut dikarenakan Macaca sering merusak perkebunan dan mencuri hasil kebun. Oleh karena itu, masyarakat menganggap, bahwa dengan memberi makan pada Macaca di daerah mereka akan mengundang Macaca tersebut untuk seringsering datang sehingga memperbesar peluang untuk mencuri hasil kebun warga. Untuk menghindari hal tersebut, pakan yang kami berikan kepada Macaca merupakan pakan yang tidak tersedia di daerah home range sehingga mereka tidak akan terbiasa dengan pakan tersebut. Selain konflik dengan warga lokal, tantangan lain yang kami hadapi yaitu salah satu home range mereka berada di jalan poros Tawaeli-Toboli. Kehadiran Macaca di tepi jalan akan menarik perhatian pengguna jalan sehingga mereka akan berhenti untuk melihat, memberi makan serta mengambil gambar sehingga dapat mengganggu proses habituasi. 


\begin{tabular}{|c|c|c|c|}
\hline No & Individu (nama sebutan) & Jenis Kelamin dan struktur umur & Spesies \\
\hline 1 & Alice & Betina Dewasa & M. hecki \\
\hline 2 & Alfamale & Jantan Dewasa & M. tonkeana \\
\hline 3 & Codet & Jantan Remaja & M. tonkeana \\
\hline 4 & Jidat & Jantan Dewasa & M. hecki \\
\hline 5 & Lukas & Jantan Dewasa & M. hecki \\
\hline 6 & Mizi & Betina Dewasa & M. hecki \\
\hline 7 & Cantik & Anak & M. hecki \\
\hline 8 & Caca & Betina Remaja & M. hecki \\
\hline 9 & Mona & Betina Remaja & M. hecki \\
\hline 10 & Zaza & Anak & M. hecki \\
\hline 11 & Zizi & Anak & M. hecki \\
\hline 12 & - & Betina Dewasa & M. hecki \\
\hline 13 & - & Betina Dewasa & M. hecki \\
\hline 14 & - & Betina Remaja & M. hecki \\
\hline 15 & - & Jantan Dewasa & M. hecki \\
\hline 16 & - & Anak & M. tonkeana \\
\hline 17 & - & Jantan Dewasa & M. hecki \\
\hline 18 & - & Jantan Remaja & M. hecki \\
\hline 19 & - & Betina Remaja & M. tonkeana \\
\hline 20 & - & Jantan Remaja & M. hecki \\
\hline 21 & - & Bayi & - \\
\hline 22 & - & Bayi & - \\
\hline 23 & - & Bayi & - \\
\hline
\end{tabular}

Tabel 3. Nama setiap individu kelompok bercampur M. tonkeana dan M. hecki

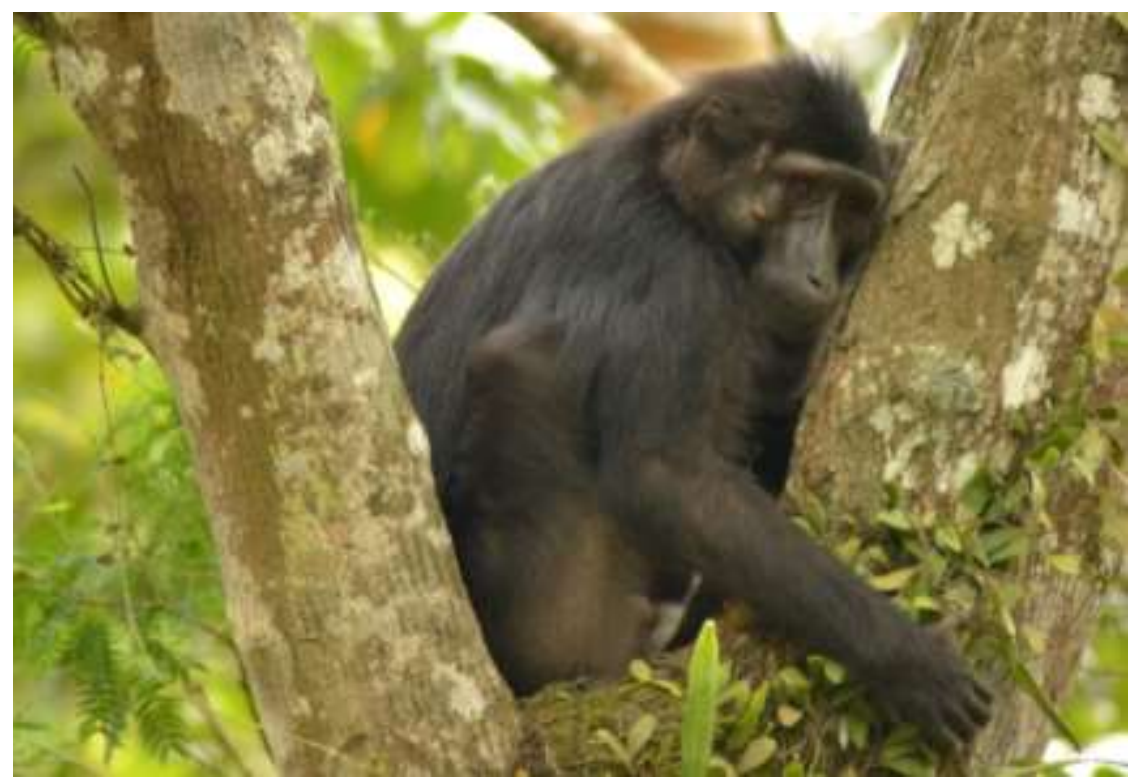

Gambar 2. Codet (remaja jantan yang memiliki bekas luka di bagian pipi) sedang istrahat di batang pohon Leucaena leucocephala 


\section{SIMPULAN}

Habituasi berhasil dilakukan pada satu kelompok Macaca tonkeana-hecki di cagar Alam Pangi Binangga selama 98 hari. Kelompok tersebut ialah kelompok Gunung batu yang terdiri dari 4 M. tonkeana dan 19 M. hecki. Habituasi di lakukan di sekitar tebing dan jurang atau di tepi sungai yang merupakan lokasi pertama kali kami bertemu. Beberapa faktor yang mempengaruhi proses habituasi yaitu lokasi yang curam dan terjal, cuaca yang buruk (hujan dan kabut tebal) serta konflik dengan warga lokal.

\section{UCAPAN TERIMA KASIH}

Terima kasih kepada Balai Konservasi Sumber Daya Alam (BKSDA) atas izin penelitian di Cagar Alam Pangi Binangga. Terima kasih kepada Irfan, Moh. Rafil, Chairunnisa dan Nurliana H. Laewa yang telah membantu dalam proses habituasi hingga selesai.

\section{DAFTAR PUSTAKA}

Balai Konservasi Sumber Daya Alam (BKSDA), 2010, Cagar Alam Pangi Binangga Sulawesi Tengah, Palu. http://www.bksdasulteng.com. Akses Mei 2017.

Curtis, D. J., 1998, Group size, home range use and seasonal variation in the ecology of Eulemur mongoz, Int. J. Primatol Vol 19:811-35.

Elizabeth, A., and Anna, T. C. F. E., 2003, Habituating primates: processes,techniques, variables and ethics, In Joanna, M. S., and Deborah, J. C., Field and Laboratory Methods in Primatology: A Practical Guide, Vol2:25-39. Cambridge: Cambridge University Press.
Joanna, M. S., and Deborah, J. C., 2003, Field and Laboratory Methods in Primatology: A Practical Guide,Cambridge: Cambridge University Press.

Kinnaird, M. F., and O'Brien, T. G., 1996, Ecotourism in the Tangkoko Dua Sudara Nature Reserve: Opening Pandora's box?, Oryx Vol30:65-73.

Rasmussen, D. R., 1991, Observer influence on range use of Macaca arctoides after 14 years of observation?, Lab. Prim. Newsl Vol30:6-1.

Watanabe, K., Lapasere, H., and Tantu, R., 1991, External characteristics and associated developmental changes in two species of Sulawesi macaques, Macaca tonkeana and Macaca hecki, with special reference to hybrids and the borderland between the species, Primates Vol 32:61-76 